relied on American immigration laws, which greatly facilitated settlers in a new place. However, Ukrainian organizations and foundations, created by the first settlers from Western Ukraine and supporting the national language and culture abroad, also took part in the adaptation of Ukrainians. Public organizations created in the United States over the past three decades by Eastern Ukrainians support the development of science and education among representatives of the Ukrainian diaspora. The widespread opinion that Ukrainians in the United States are widely incorporated into American science, education and the structure of American power is not supported by the facts, although individual cases of their successful integration do take place. The Ukrainian diaspora strives to preserve the Ukrainian language and Ukrainian identity in the United States, despite the fact that the majority of post-Soviet immigrants from Ukraine in the overwhelming majority today use Russian in everyday communication.

Keywords: Ukrainians, general Soviet mentality, peculiarities of waves of Ukrainian emigration, activities of Ukrainian organizations in host countries, preservation of Ukrainian identity abroad, professional implementation of representatives of Ukrainian diaspora in United States

САФОНОВА Наталия Вячеславовна - младший научный сотрудник Института востоковедения РАН (107031, Россия, г. Москва, ул. Рождественка, 12/1, cmp. 1, safonovanat@gmail.com)

\title{
ДИСКУССИИ О ПРОБЛЕМЕ РАДИКАЛИЗАЦИИ ИСЛАМА ВО ФРАНЦИИ НАЧАЛА ХХІ в.
}

\begin{abstract}
Аннотация. Начиная с 70-х гг. прошлого века исламские радикалы периодически организовывали нападения на мирное население Франции. Самыми массовыми по числу жертв стали теракты, совершенные в ноябре 2015 г. С тех пор дискуссии об исламистах, иммиграционной политике заполнили не только франкоязычные, но и мировые СМИ. Среди исследователей, изучающих современных мусульманских иммигрантов и феномен экстремизма, наиболее известны Ж. Кепель и О. Руа. Их полемику на тему радикализации ислама или исламизации радикализма чаще всего приводят ученые и журналисты, чтобы объяснить появление и распространение исламских экстремистских идей среди иммигрантов. В статье автор рассматривает основные дискуссии по проблеме радикализации ислама, которые ведутся с начала XXI в., и то отражение, которое они нашли в современном медийном дискурсе.
\end{abstract}

Ключевые слова: исламизм, Франция, исламский экстремизм, радикальный ислам, радикализация ислама

B о Франции проживают около 5,43 млн мусульманских мигрантов, и это число постоянно растет: каждый год ислам принимают около 3600 чел., что делает ислам второй религией после христианства. Мусульмане, проживающие на территории страны, этнически многообразны. Большинство из них представлено иммигрантами из Магриба (примерно $80 \%$ общего числа), из которых 40\% - выходцы из Алжира, почти 30\% - из Марокко, остальные - из Черной Африки [Бибикова 2015: 275]. Что касается практикующих мусульман, то их число также растет: согласно опросам, в 2006 г. на приоритет мусульманской идентификации по отношению к гражданской указали 46\%, а в 2013 г. 75\% [Жолудева 2019: 134]. Также растет число мусульман, разделяющих исламистскую радикальную идеологию, как и число людей, принимающих радикальную версию ислама.

Проблема радикализации является предметом многолетней полемики двух выдающихся исследователей современного ислама - Оливье Руа и Жиля Кепеля. О. Руа считает, что к причине появления радикалов исламизм имеет мало отношения: он разрабатывает концепцию исламизации радикализма, где 
«центральным моментом в понимании проблемы радикализации должно быть осознание феномена нигилизма». Исламисты хотят порвать с окружающей их действительностью, и в условиях глобализации и декультурации они начинают искать «чистую религию», свободную от культурных влияний.

Этап декультурации, который переживает ислам, по мнению О. Руа, означает, что он оторван от своей исторической родины и не связан с арабской культурой. Особенно это заметно на примере принявших недавно ислам жителей Франции, 25\% которых становятся радикалами. Вкупе с другой тенденцией - индивидуализацией религии - умма для них больше не связывается с конкретной территорией. Они считают, что вести джихад за свои убеждения можно, кочуя из Чечни в Сирию. Такие экстремисты, часто новообращенные, хотят присоединиться к глобальному исламистскому проекту и бороться за новые убеждения. О. Руа считает, что причины появления современного радикального и экстремистского ислама в Европе лежат в маргинальности новообращенных. Этих людей не интересует ислам как таковой, новообращенные и мигранты не первого поколения уже усвоили ценности французского общества, и накопившийся протест выплескивают «на языке ислама».

Такой вывод сделал О. Руа, проанализировав около сотни биографий джихадистов, между которыми не нашел какого-то общего для всех психологического или социального паттерна, но отметил, что все они находятся в русле французской культуры, а «язык ислама» используют для выражения протеста. В том, что касается исламистских организаций, особо важен выдвигаемый О. Руа тезис, что политического ислама как такового не существует ни в европейских, ни в мусульманских странах. Когда эти организации становятся частью политической игры, «то в них радикализм уступает место национализму, т.е. происходит “национализация исламизма” " [Осипов 2020]. Поэтому, когда исламистские организации приходят к власти, они начинают проводить политику более умеренную, руководствуясь национальными интересами, и отказываются от глобальных устремлений.

Другая важная идея О. Руа в отношении джихадистов заключается в том, что они хотят добровольно принять смерть и возвеличивают эту идею. Вместо того, чтобы посвящать себя проблемам местных мусульман, они выбирают путь построения халифата через смерть. Это отличает их от других радикалов и революционеров: они ненавидят окружающее общество (неважно, западное оно или мусульманское), и в массовых терактах и нападениях убивают себя вместе с тем миром, который они отвергают 1 .

С Оливье Руа полемизирует другой известный французский исследователь Жиль Кепель, который выводит концепцию радикализации ислама. Он считает, что тенденция к радикализации стала проявляться с маршей беров в 1983 г, , а ее появление, как и распространение джихадистских идей, изначально связано с экономическими причинами, а затем - с пропагандой радикальных имамов в бедных районах. Именно работа фундаменталистских и салафитских организаций является следствием интенции «борьбы с неверными» и распространения радикального ислама, в т.ч. и в его экстремистской форме.

Интересно, что, делая свои столь различные выводы, авторы анализируют примерно одни и те же факты: принятие радикального ислама в основном происходит в небольших пригородах/окраинах, тюрьмах и мечетях, исламских центрах и библиотеках, спортивных центрах; большую роль играет и вербовка ИГИЛа (запрещена в РФ), о чем свидетельствует число джихадистов с

${ }^{1}$ Roy O. 2017. Who are the new jihadis? - The Guardian. 13.04. URL: https://www.theguardian. com/news/2017/apr/13/who-are-the-new-jihadis (accessed 29.08.2021). 
французскими паспортами. В этих местах есть возможность для распространения и принятия радикального ислама, салафитской литературы и идеологии. Ж. Кепель делает из этого вывод, что социально-экономические причины не столь важны, как религиозные, пропагандируемые фундаменталистскими организациями.

Социолог Ф. Хосрохавар объясняет феномен появления исламских экстремистов эмоциональной составляющей, а именно наличием сильно переживаемого унижения и отторжения со стороны окружающего общества. Унижение может быть прямым, как при столкновении с расизмом, или опосредованным, в частности в результате самоидентификации с палестинцами. При этом «унижение действует как одна из важнейших эмоций, способствующих вовлечению в (радикальный) исламизм». Экстремисты клеймят Запад как «аморальный», «Гнилой», «бесстыдный», их возмущают откровенная манера одеваться и беспорядочные отношения между полами [Ланмин 2017].

Другой исследователь Ж. Радвани среди факторов радикализации выделяет такие, как непрочность или разрушение семейных и социальных связей, ощущение несправедливости на местном уровне или в мировом масштабе, потребность в новых идеологических ориентирах в окружающем быстро меняющемся мире, роль Интернета и социальных сетей и т.п.

Кроме того, большинство дискуссий выстраивается вокруг вопроса, можно ли считать, что проблема появления исламских радикалов вызвана чисто религиозными причинами или же кризисом идентичности. Ф. Фукуяма ${ }^{1}$ в своей последней книге, во многом посвященной национализму и религии, объединяет две точки зрения - Ж. Кепеля и О. Руа, считая, что большинство сегодняшних конфликтов, включая Арабскую весну, связаны с тем, что политика идентичности, в которой индивидуальность требует признания собственной значимости, стала центральной в политической игре. То, что именно проблема идентичности (религиозной и расовой) является основной в процессе становления исламских радикалов, считают и классики антропологии ислама Э. Геллнер и К. Гирц.

Так, К. Гирц считает, что проблема религиозной идентичности возникает потому, что ислам начинает осознавать себя в чужой, немусульманской стране. Таким образом, формируется «религиозное мышление» 2 , при котором мусульмане начинают рефлексировать на тему своей одежды, еды и других религиозных атрибутов - всего того, что раньше не требовало рефлексии, а было естественным на исторической родине. Таким образом, возникает новый контекст, который определяет ислам, и персональное ощущение мусульманина в ином контексте становится определяющим фактором его идентичности ${ }^{3}$.

С ним согласны и другие авторы, которые считают, что из-за кризиса идентичности и политики интеграции сами мусульмане начинают практиковать исключение из окружающего общества. Делают они это двумя способами: во-первых, в отношении внешнего мира, усваивая чувство превосходства над немусульманами, поскольку «другие религии не такие, как ислам, и потому хуже», во-вторых, внутри собственного сообщества, навязывая другим мусульманам жесткий тип религиозной ортодоксии, например в случае салафитов-

\footnotetext{
${ }^{1}$ В его концепции «конца истории» альтернативой кризисной и тупиковой модели капиталистического развития являются либо левые режимы, либо уход «в архаичные общества», например исламское государство.

2 По определению К. Гирца, который отличает религиозное мышление от простой веры. Интервью с Клиффордом Гирцем. 2016. Доступ: http://islamoved.ru/2016/islam-modernnatsionalizm-intervyu-s-kliffordom-girtsem/(проверено 29.08.2021).

3 Там же.
} 
неотрадиционалистов на Западе. Тогда часто возникают радикальные и даже экстремистские тенденции. При этом важно понимать, что мусульманская идентичность не фиксирована и не статична, а представляет собой эволюционный процесс становления ${ }^{1}$.

Франсуа Бурга, еще один французский исследователь, которого иногда ставят в один ряд с О. Руа и Ж. Кепелем, в своей книге «Понимание политического ислама» пытается реполитизировать исламизм и джихадизм и предложить другое объяснение их появления. Основными причинами он называет колониальное прошлое ${ }^{2}$, продолжающееся стремление Запада к гегемонии, дискриминацию со стороны европейских обществ, складывание негативного образа мусульманского Другого, который множит насилие и отбирает у мусульман право на самоопределение. Кроме того, нельзя забывать о многообразии исламистских движений, которые не сводятся только к фундаментализму и экстремизму: какие-то движения могут со временем радикализироваться, а другие - становиться более умеренными. Поэтому исламизм и джихадизм это попытка возвратить ислам на международную геополитическую арену. Она «является не столько результатом идеологии, сколько производным от новых политических идентичностей». Исламизм в геополитическом смысле - это «глобальная борьба мусульман против колониального угнетения и постколониального модернизма, в рамках которого новые независимые страны стремились развиваться по европейскому образцу» ${ }^{3}$. И сегодня исламизм представляет собой третий этап деколонизации, когда он борется не только с западными режимами, но и с застоявшимися националистическими режимами, такими как БААС. А формы он может принимать различные - от демократичного исламизма, представленного правлением партии Ан-Нахда в Тунисе, до экстремистского в виде Исламского государства.

То, что на Ближнем Востоке народ часто выбирает исламистов в ходе демократических выборов, говорит о необходимости включения их в политическую сферу, иначе политически активные мусульмане будут уходить в подполье и брать в руки оружие.

Схожее мнение высказывает и Б. Хоффман, указывая, что в Европе сложилось четкое представление, что быть европейцем - значит быть христианином и просвещенным либералом, соблюдать римское право. Поскольку правильной признана такая европейская идентичность, то мусульман можно обвинять в неспособности к интеграции и стремлении к сепаратизму и изоляционизму [Haut 2007].

Акцент на постколониальном аспекте делает еще один современный исследователь Х. Бенесс, который приводит слова французского госсекретаря по вопросам работников-мигрантов (1974-1977) П. Дижуда о том, что проблема мигрантов, прибывших из бывших колоний, в том, что они не готовы к контакту с цивилизацией, где преобладает рациональность и технологии. Х. Бенесс отмечает, что нужно вернуться к тому моменту истории, когда иммигранты вдруг стали ассоциироваться с «проблемой», и деконструировать само понятие

\footnotetext{
1 Там же.
}

2 Следует отметить, что и Ж. Кепель и О. Руа писали о том, что ввиду популярности постколониальных исследований многие исламисты могут использовать «научные» данные для борьбы и оправдания исламского экстремизма. Оба исследователя считают, что геополитические причины, безусловно, играют большую роль, но скорее являются только одним из факторов появления исламских экстремистов.

3 Почему Запад пытается очернить «политический ислам»? - Все про арабский мир. 26.08.2020. Доступ: https://arabmir.net/analiz/pochemu-zapad-pytaetsya-ochernit-politicheskiy-islam (проверено 29.08.2021). 
иммигрантов, которое претерпело наслоение множества новых коннотаций. Таким же образом нужно деконструировать понятия «ислам», «пригороды», «дети такого-то происхождения» ${ }^{1}$.

Итак, проблема радикализации ислама во Франции занимает большое место в дискурсе европейских и, в частности, французских ученых. Этот дискурс влияет и на медиа, и на позицию политиков. Однако в СМИ до сих пор превалирует понимание ислама как «корня зла», как основной причины неудачной интеграции мусульман во французское общество, как фактора, способствующего разделению общества, его сегрегации. От этого страдают обычные мусульмане - французы второго и третьего поколения, которым запрещается выражать религиозную идентичность; идет демонизация ислама и исламизма, а также образа самого мусульманина и, как следствие, рост исламофобских настроений, с одной стороны, и популярность радикальных идей - с другой.

Мнения ученых об идейных причинах радикализации расходятся, поэтому важной представляется борьба не с идеологией, а с насилием. Негативное отношение к самому исламу привело к понятиям «правильного», умеренного ислама (также называемого «французским исламом») и «неправильного», радикального. О. Руа, комментируя это явление, отметил, что главное - это что «говорят сами мусульмане по поводу того, о чем говорится в Коране». Поскольку люди всегда спорили и будут спорить о том, что написано в священных книгах, эти тексты открыты для интерпретации, как бы сильно последователи религии ни хотели оставить их неизменными. Принципы, закрепленные в исламской религии, можно трактовать по-разному. Важно, какие именно методы, насильственные или нет, выбирает последователь религии для выстраивания своей идентичности и борьбы за социальную справедливость.

\section{Список литературы}

Бибикова О.П. 2015. Иммигранты из мусульманских стран в Европе: этноконфессиональный и социокультурный аспекты. М.: Изд-во ИВ РАН. 376 с.

Жолудева Н.Р. 2019. Мусульмане во Франции: жизнь мусульманских кварталов Парижа. - Вестник Томского государственного университета. № 438. C. $132-137$.

Ланмин А.С. 2017. Вера-идентичность, вера-убеждение и радикализм: опыт социологического анализа. - Религии и радикализм в постсекулярном мире. М.: Изд-во ИЭА РАН. С. 301-314.

Осипов Е.А. 2020. Споры о французском мультикультурализме. От исламизации радикализма к радикализации ислама? - Новая и новейшая история. № 6. С. $179-187$.

Haut F. 2007. Terrorism and Diasporas in France. - Radicalization, Terrorism, and Diasporas. . A Joint Conference by the RAND Corporation and the Center for Security Studies. RAND Corporation P. 23-25.

\footnotetext{
${ }^{1}$ Benaissa H. 2018. Le mythe du retour, le renversement d'un mythe :sociohistoired'une «crise identitaire. - Cahiers d'études du religieux. Recherchesinterdisciplinaires. № 19. Доступ: http:// journals.openedition.org/cerri/2527 (проверено 29.08.2021).
} 
SAFONOVA Natalia Vyacheslavovna, Junior Researcher of the Institute of Oriental Studies of the Russian Academy of Sciences (bld. 1, 12/1 Rozhdestvenka St, Moscow, Russia, 107031; safonovanat@gmail.com)

\title{
DISCUSSIONS ABOUT THE PROBLEM OF RADICALIZATION OF ISLAMIN FRANCE AT THE BEGINNING OF THE 21 ST CENTURY
}

\begin{abstract}
Since the 1970s, Islamic radicals periodically have organized attacks on the civilian population of France. The most massive, in terms of the number of victims, were the terrorist attacks committed in November 2015. Since then, discussions about Islamists and immigration policy have filled not only the French-language media, but also the world ones. The most famous among the researchers studying modern Muslim immigrants and the phenomenon of extremism, are J. Kepel and O. Rua. Scholars and the media to explain the emergence and spread of Islamic extremist ideas among immigrants most often cite their polemics on the radicalization of Islam or Islamization of radicalism. The author considers the main discussions on the problem of radicalization of Islam, which have been going on since the beginning of the $21^{\text {st }}$ century, and how they reflect the modern media discourse.
\end{abstract}

Keywords: Islamism, France, Islamic extremism, radical Islam

ЛОБАНОВА Ольга Николаевна - доцент Дипломатической академии МИД России (119021, Россия, г. Москва, ул. Остожкенка, 53/2, стр. 1; lobanovaon1954@gmail.com)

\section{КАТАЛОНСКИЙ СЕПАРАТИЗМ: ПРИЧИНЫ И ПЕРСПЕКТИВЫ}

\begin{abstract}
Аннотация. Испания является полиэтническим государством, на территории которого проживают крупные группы этнокультурных меньшинств, составляющие одну пятую часть всего населения королевства. Классической проблемой Королевства Испания, наблюдаемой на протяжении веков, является феномен глубинного национального самосознания народностей, составляющих единую страну. Наиболее неспокойным автономным сообществом остается Каталония, население и власть которой стремятся к отделению от Королевства Испания и созданию собственного суверенного государства.
\end{abstract}

Ключевые слова: этнокультурные меньшинства, региональный конфликт, Испания, каталонский сепаратизм, каталонизм

$\mathrm{B}$ целях детального анализа феномена подъема национального самосознания на территории «каталанских земель» Королевства Испания в первую очередь необходимо раскрыть содержание категории сепаратизма, а также подробно рассмотреть причины его возникновения. На основе полученного материала представляется возможным дать оценку перспектив каталонских националистических процессов, что является основополагающей целью настоящего исследования. В ходе достижения поставленной цели сопутствующими задачами обозначаются изучение политико-административного, социально-экономического, этнокультурного оснований каталонского сепаратизма, а также рассмотрение динамики национального самосознания каталонцев в историческом контексте.

Центральная проблема категории сепаратизма состоит в определении ее содержания. Главная сложность заключается в минимальном отражении ука- 